\title{
Clinicopathologic retrospective analysis of annular pustular psoriasis
}

\author{
Agnieszka Owczarczyk-Saczonek ${ }^{1 凶}$, Aleksandra Znajewska-Pander ${ }^{1}$, Witold Owczarek ${ }^{2}$, Agata Maciejewska-Radomska ${ }^{3}$, \\ Waldemar Placek ${ }^{1,3}$
}

\begin{abstract}
Annular pustular psoriasis (APP) is a rare form of pustular psoriasis with a chronic relapsing course and a good prognosis. The clinical picture is characterized by erythematous lesions, usually polycyclic, with the presence of small, sterile pustules on the circumference of the lesions and fine peeling. We present two cases of APP with diagnostic problems: a 65-year-old woman that suffered from intermittent APP with remission and exacerbation for many years, and an 83-year-old man with lesions that developed after atenolol treatment. In both cases, the patients were thought to have drug provocation, and therefore acute generalized exanthematous pustulosis (AGEP) was diagnosed. Only a thorough analysis of the course of the disease and histopathological examination allowed correct diagnosis. The clinical picture of APP is similar to AGEP, generalized pustular psoriasis (GPP), also known as von Zumbusch pustular psoriasis, and subcorneal pustular disease, and it requires accurate differential diagnosis.
\end{abstract}

Keywords: annular pustular psoriasis, acute generalized exanthematous pustulosis, drug provocation

Received: 16 December 2017 | Returned for modification: 3 May 2018 | Accepted: 26 June 2018

\section{Introduction}

Annular pustular psoriasis (APP) was first described by Milian and Katchoura in 1933 as "psoriasis pustulosa benigna" (1). It is a rare type of psoriasis that occurs with or without a history of psoriasis (2).

There are four subtypes of pustular psoriasis: 1) generalized (or von Zumbusch) pustular psoriasis (GPP), 2) annular (or circinate) pustular psoriasis (APP), 3) guttate (exanthematic) pustular psoriasis, and 4) localized pustular psoriasis (3, 4). Some dermatologists classify mixed variants (mixed pustular psoriasis, MPP) with the characteristics of both generalized and circinate pustular psoriasis (3). Types of APP are also referred to as "erythema circine recidivants," "La Piere type of psoriasis," or "psoriasis type of erythema annulare centrifugum” $(3,5)$.

APP is a rare form of pustular psoriasis with a chronic relapsing course and a good prognosis. It is different from GPP because it has a more subacute and limited clinical course $(6,7)$. In the literature, APP most often occurs in children, and the cases described involve siblings and twins $(3,8-12)$. The chance of spontaneous remission is higher in children than in adults. Triggering factors are stress, infections, and withdrawal of systemic corticosteroids $(3,9,11)$.

The clinical picture is characterized by erythematous lesions that are usually polycyclic, with the presence of small, sterile pustules on the circumference of the lesions and fine peeling. Eruptions extend circumferentially and disappear within a few weeks, sometimes leaving little hyperpigmentation $(6,9,13)$. The lesions have a concentric arrangement: paler skin in the center or slight erythema, surrounded by a ring-shaped rash and by numerous pustules. The pustules are often confluent and disappear in the form of "collarette-like" exfoliation $(1,14)$. There are frequent relapses in adjacent areas (13). The lesions are located on the limbs, buttocks, and abdomen. The face, hands, and feet usually remain free of symptoms. The lesions resemble pustular psoriasis on the mucous membranes of the mouth and tongue $(1,13,14)$. It is not a typical psoriasis, which makes the diagnosis more difficult (1).

Specific triggering mechanisms for APP are unknown. Occasionally throat infection, menses, pregnancy, medications, UV radiation, or emotional stress have been considered to provoke the eruption (7). There have been a number of case reports on the concurrence of annular psoriasis and pemphigus foliaceus that developed in preexisting psoriasis lesions (15). In pemphigus, neutrophilic infiltration was caused by IgG autoantibody-induced interleukin (IL)-8 expression in keratinocytes (15). In addition, psoriasiform eruptions are thought to be a paraneoplastic manifestation (16).

We present two cases of APP with diagnostic problems.

\section{Case 1}

We present the case of a 65-year-old Caucasian female patient that had suffered from intermittent APP with remission and exacerbation since 2008. She was hospitalized at the Department of Dermatology, Sexually Transmitted Diseases and Clinical Immunology in Olsztyn several times.

In addition to the patient's skin lesions, she also has hypertension and a benign nodule in the thyroid. Moreover, she is hypersensitive to grass, flower, and weed pollens, which was confirmed by allergy tests. Her family history is unrelated.

The first skin lesions of annular erythema appeared in November 2008. In the patient's opinion, the skin lesions were associated with a new drug for hypertension (the ACE inhibitor trandolapril). She was diagnosed with AGEP (acute generalized exanthematous pustulosis). GPP was ruled out because the lesions did not involve all of the body regions and the patient was in good physical condition. During hospitalization, the medication for hypertension was changed and the patient was treated with prednisone at a dose of $20 \mathrm{mg} /$ day and glucocorticosteroids topically, showing clinical improvement. The patient was hospitalized again in January 2009 
because of generalized erythema with the presence of numerous small pustules on the periphery of annular erythemas (Fig. 1).

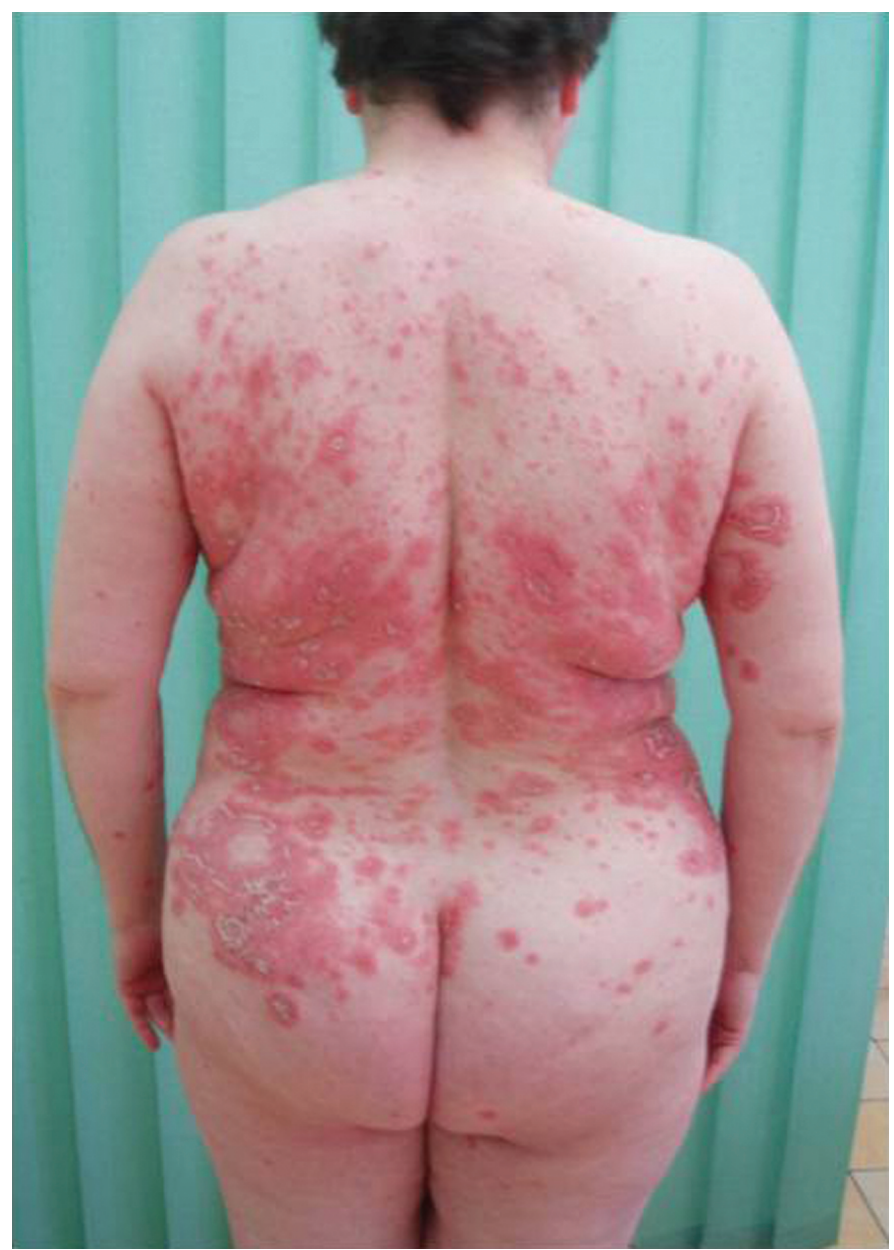

Figure 1 | 56-year-old Caucasian female patient: generalized erythema with numerous small pustules on the periphery of annular erythemas (January 2009).

Because of the recurrence of skin lesions without a fixed triggering factor, a skin biopsy was taken for histopathological and immunopathological examination, and erythema annulare-like acantholytic dermatosis was suspected. After histopathological examination, no acantholysis features were observed, and the clinical picture corresponded to subcorneal pustular dermatosis. On the basis of the clinical picture and additional tests, subcorneal pustular disease was diagnosed, although direct immunofluorescence (DIF) revealed only deposits of fibrinogen around the blood vessels and antibodies of the pemphigus type (IgG, IgA) were negative. Methylprednisolone therapy did not improve the skin lesions. Then the patient was treated with sulfones, after which there was an increase in methemoglobin. Due to intolerance of this treatment, she was given acitretin with a remission of the illness. Another eruption of erythematic lesions occurred in December 2009, with a similar morphology as before, and so acitretin was used again with a 5-year remission.

In August 2015, the patient was hospitalized due to general lesions. Dermatological examination revealed well-demarcated, polycyclic erythematous lesions, with the presence of small pustules on the trunk, neck, and extremities. Eruptions extended circumferentially, accompanied by fever and malaise, and disappeared within a few weeks, leaving hyperpigmentation (Fig. 2). The patient complained of a burning sensation on the skin. Routine biochemical tests, including renal and liver function, were normal. Full blood count revealed leukocytosis (21.2 g/l) with neutrophilia (78\%) and elevated CRP (42.3 mg/dl). Blood cultures, thyroid function, other biochemical tests, and electrophoresis were normal. Indirect immunofluorescence test (IIF; antibodies pemphigus and pemphigoid type) was negative. DIF showed deposits of fibrinogen in the papillary region of the dermis only. Histopathological examination revealed subcorneal pustules, acanthosis, perivascular lymphocytic infiltration, and focal swelling of the skin (Fig. 3).

On the basis of the above tests and a careful medical interview (the patient recalled previous symptoms of psoriasis in her childhood), APP was diagnosed. The patient was treated with erythromycin and acitretin $50 \mathrm{mg} /$ day $(0.6 \mathrm{mg} / \mathrm{kg}$ ) with good results. The last hospitalization was in May 2016, caused by the appearance of new lesions due to reduction of the acitretin dose because of fingernail paronychia. After surgical consultation it was decided to remove the nail and, after healing, the acitretin dose was increased to $50 \mathrm{mg} /$ day. Since then, the patient has remained asymptomatic and she is still under observation.

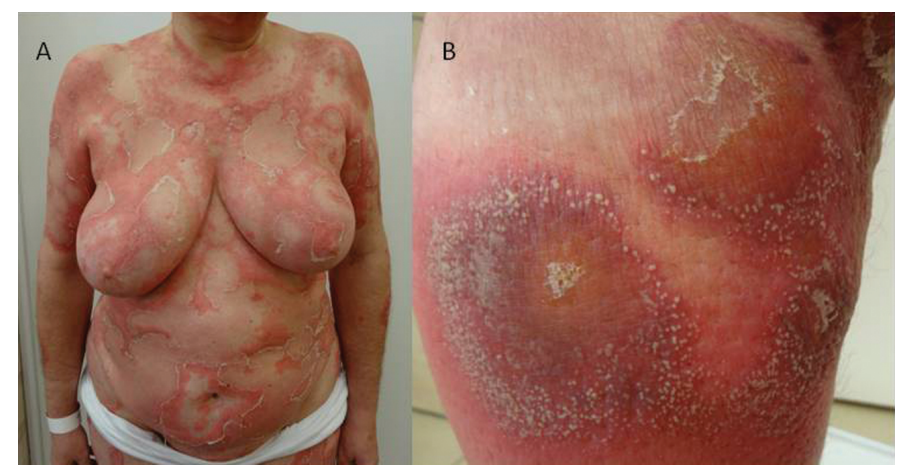

Figure 2 | The same patient: well-demarcated, polycyclic erythematous lesions, with the presence of small pustules on the circumference (A, B; August 2015).

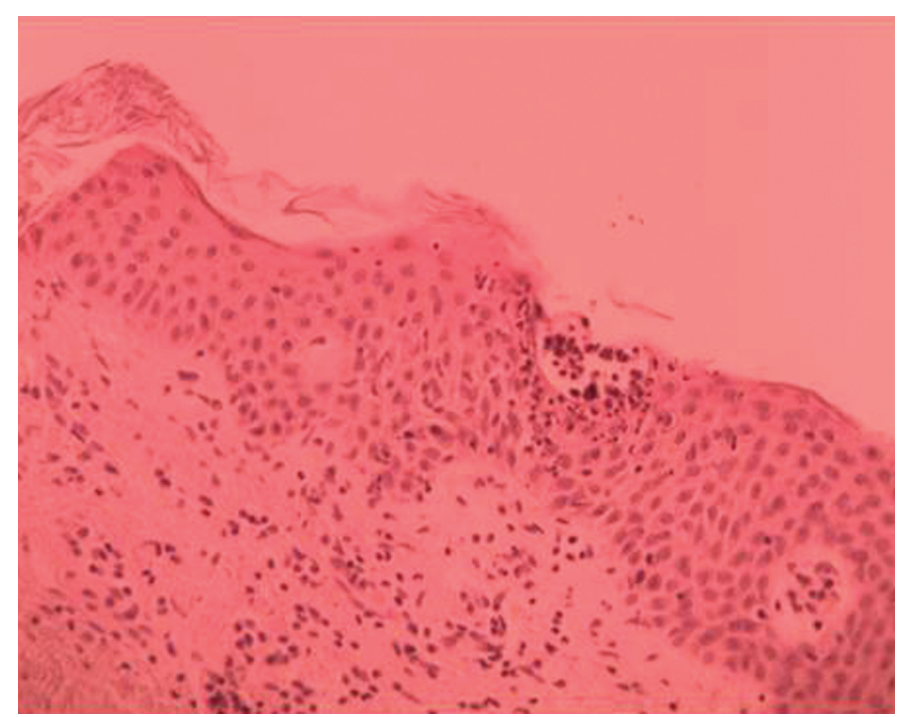

Figure 3 | Histopathological examination revealed subcorneal pustules filled with dense exudates of inflammatory cells, acanthosis, superficial capillaries, and perivascular lymphocytic infiltration as well as focal swelling of the skin.

\section{Case 2}

An 83-year-old Caucasian male patient was admitted to the Department of Dermatology at the Military Institute of Medicine in Warsaw in August 2010 due to scattered well-demarcated round lesions with the presence of small pustules on the circumference on the skin of the upper limbs, lower limbs, groin, abdomen, and chest (Fig. 4). The patient had no systemic symptoms. Skin lesions appeared 3 weeks earlier, the first time in his life, after a few weeks of taking atenolol, which could suggest AGEP, and so 
the drug was discontinued. The patient's mother's sister suffered from psoriasis. She also had metabolic syndrome (abdominal obesity, hypertension, type 2 diabetes, and atherogenic dyslipidemia). In addition, an interview revealed ischemic heart disease with angioplasty of the left anterior descending artery and stent implantation (in 2006), implantation of a pacemaker because of tachy-brady syndrome, permanent atrial fibrillation, a history of ischemic stroke (in 2003), and a euthyroid nodular goiter. Laboratory tests revealed CRP $6.08 \mathrm{mg} / \mathrm{dl}$, ESR $36 \mathrm{~mm} / \mathrm{h}$, fasting glucose $120 \mathrm{mg} / \mathrm{dl}$, fibrinogen $624 \mathrm{~g} / \mathrm{l}$, and serum albumin $3.4 \mathrm{~g} / \mathrm{l}$. Histopathological examination showed significant swelling of intracellular cells of the spiny and basal layer (spongiosis), as well as accumulation of polymorphonuclear leukocytes in the stratum corneum. The patient was treated with doxycycline $200 \mathrm{mg} /$ day and topical clobetasol propionate. We observed regression of the lesions, which left post-inflammatory hyperpigmentation. Worsening of the disease occurred in November 2010, accompanied by general weakness, lack of appetite, and chills. Laboratory studies showed ESR $68 \mathrm{~mm} / \mathrm{h}$, CRP $12.20 \mathrm{mg} / \mathrm{dl}$, fasting glucose 148 $\mathrm{mg} / \mathrm{dl}$, and fibrinogen $809 \mathrm{mg} / \mathrm{dl}$. After correct diagnosis of APP was made, the patient was treated with acitretin $50 \mathrm{mg} /$ day with a good result. Regression of lesions on the upper extremities with post-inflammatory hyperpigmentation and the appearance of a typical psoriatic plaque on the legs, chest, and scalp was observed in December 2010 (Fig. 5).

The skin lesions, which developed after a few weeks of exposure to atenolol (a beta-blocker), could suggest AGEP. However, lack of fever and neutrophilia, the location of the lesions, and a good response to retinoids suggest APP.

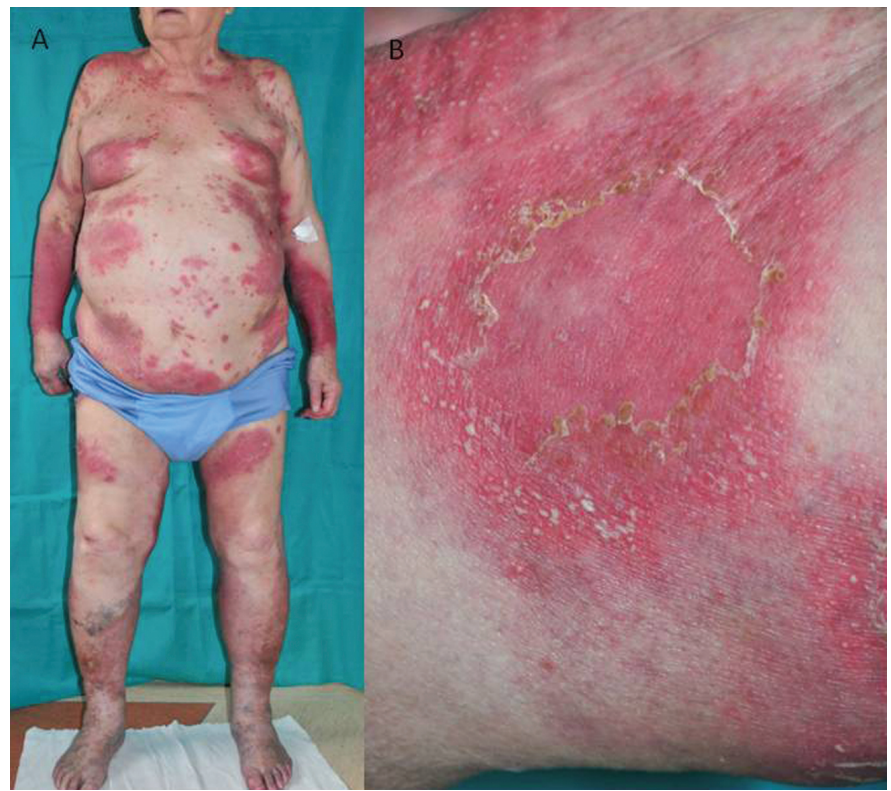

Figure 4 | 83-year-old Caucasian male patient: scattered well-demarcated, round lesions with the presence of small pustules on the circumference on the skin of the upper limbs, lower limbs, groin, abdomen, and chest (A, B; August 2010).

\section{Discussion}

APP is a rare form of pustular psoriasis with a chronic relapsing course and a good prognosis. The clinical picture is similar to AGEP, GPP, also known as von Zumbusch pustular psoriasis, and subcorneal pustular disease, also known as Sneddon-Wilkinson disease, and thorough differential diagnosis must be carefully carried out (Table 1).

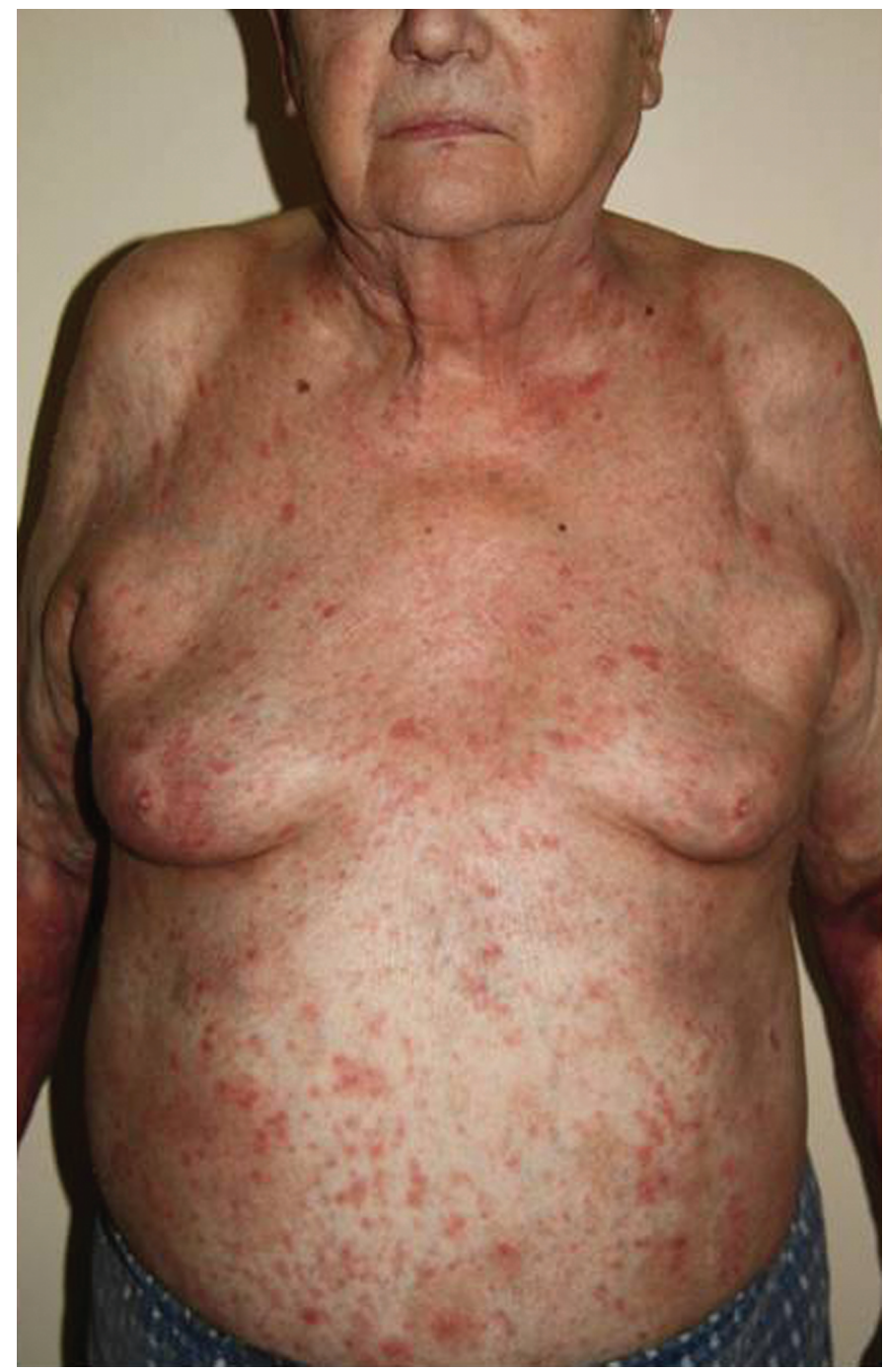

Figure 5 | After regression of annular pustular psoriasis lesions that look like typical psoriatic plaque on the legs, chest, and scalp (December 2010).

Diagnosis of APP, as a rare form of psoriasis, can be difficult. Annular or serpiginous erythemas with pustulation and collarette-like scaling must be differentiated from AGEP. Therefore, in both our cases, patients were thought to have drug provocation. AGEP is an acute spontaneous self-limiting febrile drug reaction that usually resolves within 2 weeks after withdrawal of the suspected agent. However, identification of identical mutations in patients with AGEP and GPP, a similar pathomechanism, suggests that these diseases belong to the same group of diseases, and in the case of AGEP the drug is a triggering factor (17). Therefore, the differentiation of these two diseases is very difficult $(3,18,19)$.

The differential diagnosis should also involve GPP. However, APP lesions are not confluent, and patients are in better clinical condition. They may be accompanied by general symptoms such as fever, malaise, and arthralgia, but much milder than GPP. This disease is usually recurrent: it has a short duration with a cyclical course, or it can recur after several years, as in Case 1 presented here $(1,2)$.

Homozygous or compound heterozygous IL36RN gene mutations underlie the pathogenesis of psoriasis-related pustular eruptions including GPP, palmoplantar pustular psoriasis, acrodermatitis continua of Hallopeau, and $\operatorname{AGEP}(17,20)$. Thus, patients may present various phenotypes throughout their lives (as in Case 1). Mutation of the IL36RN gene-which encodes the anti-inflammatory cytokine IL-36 receptor antagonist, a protein belonging to the 
IL-1 cytokine family responsible for the tight regulation of IL-36 signaling-causes "deficiency of the IL-1 receptor antagonist" and may be a genetic risk factor for $\operatorname{APP}(21,22)$. Catharino et al. proposed that APP is possibly induced by RAS/MAPK signaling activation. This signaling pathway receives extracellular stimuli from cell surface receptors and acts as a molecular switch in the

Table 1 | Differential diagnosis of AGEP (acute generalized exanthematous pustulosis), APP (annular pustular psoriasis), SPD (subcorneal pustular dermatosis), and GPP (generalized pustular psoriasis).

\begin{tabular}{|c|c|c|c|c|}
\hline & AGEP & APP & SPD & GPP \\
\hline Clinical presentation & $\begin{array}{l}\text { - Areas of red skin } \\
\text { studded with numerous } \\
\text { small sterile pustules; } \\
\text { - Acute course with } \\
\text { spontaneous pustules } \\
\text { in } 5 \text { days; } \\
\text { - Resolves spontaneously } \\
\text { with slight } \\
\text { hyperpigmentation }\end{array}$ & $\begin{array}{l}\text { - Erythematous lesions usually } \\
\text { polycyclic, with the presence } \\
\text { of small, sterile pustules on } \\
\text { the circumference and fine } \\
\text { peeling; } \\
\text { - Centrally paler skin or slight } \\
\text { erythema, surrounded by } \\
\text { raised ring-shaped rash and } \\
\text { numerous pustules; } \\
\text { - Pustules often confluent } \\
\text { and disappear in the form of } \\
\text { "collarette-like" exfoliation; } \\
\text { - Mild hyperpigmentation often } \\
\text { remaining after pustular } \\
\text { lesions have resolved }\end{array}$ & $\begin{array}{l}\text { - Many flaccid pustules, } \\
\text { several millimeters in } \\
\text { diameter, on normal or } \\
\text { mildly erythematous } \\
\text { skin; } \\
\text { - Classic lesion described } \\
\text { as a “half-half” blister, } \\
\text { in which purulent fluid } \\
\text { accumulates in the lower } \\
\text { half of the blister; } \\
\text { - Isolated or confluent } \\
\text { pustules tend to form } \\
\text { annular, circinate, or } \\
\text { serpiginous patterns; } \\
\text { - Pustules result in a } \\
\text { superficial crust; } \\
\text { - Mild hyperpigmentation } \\
\text { after recovering }\end{array}$ & $\begin{array}{l}\text { - Skin initially fiery red and } \\
\text { tender; } \\
\text { - Areas of red skin studded } \\
\text { with numerous small } \\
\text { sterile pustules; } \\
\text { - Gradual involvement of } \\
\text { the whole skin; } \\
\text { - Pustules coalesce within } \\
1 \text { day to form lakes of pus } \\
\text { that dry and desquamate } \\
\text { in sheets, leaving behind } \\
\text { a smooth, erythematous } \\
\text { surface on which new } \\
\text { crops of pustules may } \\
\text { recur }\end{array}$ \\
\hline Distribution of lesions & $\begin{array}{l}\text { Face, armpits, and groin, } \\
\text { and then spread all over } \\
\text { the body }\end{array}$ & $\begin{array}{l}\text { - Flexural sites of the trunk and } \\
\text { proximal extremities, buttocks, } \\
\text { and abdomen; } \\
\text { - Face, plantar, and palmar, } \\
\text { usually without lesions }\end{array}$ & $\begin{array}{l}\text { - Flexural sites (armpits, } \\
\text { groin, neck, } \\
\text { submammary region), } \\
\text { and proximal extremities; } \\
\text { - Palmar, plantar, face, } \\
\text { and mucous membrane } \\
\text { involvement is unusual }\end{array}$ & $\begin{array}{l}\text { - Flexural sites (armpits, } \\
\text { groin, neck, submammary } \\
\text { region) and then spread } \\
\text { all over the body; } \\
\text { - Mucosal lesion (pustules) } \\
\text { can exist }\end{array}$ \\
\hline Age and sex & $\begin{array}{l}\text { Without predilection for } \\
\text { age and sex }\end{array}$ & Children and young people & $\begin{array}{l}\text { Affects middle-aged or } \\
\text { elderly women more } \\
\text { commonly than men }\end{array}$ & $\begin{array}{l}\text { Affects middle-aged or } \\
\text { elderly people without sex } \\
\text { predominance }\end{array}$ \\
\hline General symptoms & Fever $>38^{\circ} \mathrm{C}$ & Sometimes fever, malaise & None & $\begin{array}{l}\text { Headache, fever, chills, } \\
\text { arthralgia, malaise, } \\
\text { anorexia, and nausea }\end{array}$ \\
\hline Laboratory studies & Neutrophilia > $7 \mathrm{~g} / \mathrm{l}$ & $\begin{array}{l}\text { Slight increase in inflammation } \\
\text { markers }\end{array}$ & Usually normal limits & $\begin{array}{l}\text { - Leukocytosis up to } 40 \\
\text { g/l with lymphopenia } \\
\text { coinciding with } \\
\text { neutrophilia; } \\
\text { - High inflammatory } \\
\text { markers (ESR, CRP); } \\
\text { - Decreased albumin }\end{array}$ \\
\hline Trigger factors & $\begin{array}{l}\text { Drugs (macrolides, } \\
\text { penicillins, cephalosporins } \\
\text { and quinolones, } \\
\text { hydroxychloroquine, } \\
\text { sulfonamides, terbinafine, } \\
\text { diltiazem) }\end{array}$ & $\begin{array}{l}\text { Stress, infections, abrupt with- } \\
\text { drawal of oral corticosteroids }\end{array}$ & $\begin{array}{l}\text { Infections, monoclonal } \\
\text { gammopathies, multiple } \\
\text { myeloma }\end{array}$ & $\begin{array}{l}\text { Stress, infections, drugs, } \\
\text { abrupt withdrawal of oral } \\
\text { corticosteroids, sunlight or } \\
\text { phototherapy }\end{array}$ \\
\hline Course & $\begin{array}{l}\text { Rapid appearance, } \\
\text { resolves spontaneously }\end{array}$ & $\begin{array}{l}\text { Less acute onset than AGEP, } \\
\text { often relapses }\end{array}$ & $\begin{array}{l}\text { Less acute onset than AGEP } \\
\text { and slow progress }\end{array}$ & Rapid appearance \\
\hline Histologic findings & $\begin{array}{l}\text { - Intraepidermal or } \\
\text { subcorneal pustules } \\
\text { filled with neutrophils; } \\
\text { - Edema of the skin; } \\
\text { - Perivascular infiltration } \\
\text { of lymphocytes and } \\
\text { eosinophils; } \\
\text { - Apoptotic keratinocytes }\end{array}$ & $\begin{array}{l}\text { - Similar to other types of } \\
\text { pustular psoriasis; } \\
\text { - Widening of superficial } \\
\text { capillaries and perivascular } \\
\text { lymphocytic infiltration; } \\
\text { - Focal swelling of the skin; } \\
\text { - Spongiform Kogoj pustules } \\
\text { (neutrophil infiltration of the } \\
\text { necrotic areas of the skin); } \\
\text { - Dilation of blood vessels } \\
\text { in papillary dermis without } \\
\text { vasculitis }\end{array}$ & $\begin{array}{l}\text { - Subcorneal pustules } \\
\text { composed primarily } \\
\text { of neutrophils and } \\
\text { occasional eosinophils; } \\
\text { - Epidermis usually has } \\
\text { minimal spongiosis; } \\
\text { - Dermis in subcorneal } \\
\text { pustular dermatitis } \\
\text { shows perivascular } \\
\text { infiltrate of neutrophils } \\
\text { and occasional } \\
\text { monocytes and } \\
\text { eosinophils; } \\
\text { - Acantholysis not } \\
\text { prominent }\end{array}$ & $\begin{array}{l}\text { - Parakeratosis and } \\
\text { thinning of suprapapillary } \\
\text { epidermis; } \\
\text { - Superficial dermis } \\
\text { shows mononuclear } \\
\text { infiltrate and numerous } \\
\text { neutrophils migrating } \\
\text { from papillary capillaries } \\
\text { to the epidermis; } \\
\text { - Neutrophils in the } \\
\text { epidermis can aggregate } \\
\text { between keratinocytes, } \\
\text { where there is also } \\
\text { spongiosis, forming Kogoj } \\
\text { pustules }\end{array}$ \\
\hline Patient history & $\begin{array}{l}\text { Relationship to medications } \\
\text { or viral infection, negative } \\
\text { interview for psoriasis }\end{array}$ & $\begin{array}{l}\text { Occurrence of psoriasis in } \\
\text { individual or family }\end{array}$ & $\begin{array}{l}\text { Negative personal and } \\
\text { family history of psoriasis }\end{array}$ & $\begin{array}{l}\text { Occurrence of psoriasis in } \\
\text { individual or family }\end{array}$ \\
\hline
\end{tabular}


processes of cell proliferation, differentiation, survival, and death (6). Bachelez emphasizes that mutations in IL36RN, CARD14, and $\mathrm{AP}_{1} \mathrm{~S}_{3}$ in these groups of diseases lead to an enhanced inflammatory cascade in several cellular subtypes including keratinocytes, and to the recruitment and activation of neutrophils and macrophages (17). The consequence of these phenomena is the overproduction of IL-8 and GM-CSF by CD4 + T cells, which induces chemotaxis of neutrophils and formation of pustules (22). The similar pathomechanism of these diseases makes it possible to classify them as autoinflammatory diseases and highlight similarities at the pathogenic, clinical, and histological levels between recognized genetically determined autoinflammatory diseases with skin involvement such as neutrophilic dermatoses including pyoderma gangrenosum and Sweet's syndrome (23).

The next disease that requires differentiation is subcorneal pustular disease (18). Moreover, the clinical picture of APP looks similar to necrolytic migratory erythema, annular and gyrate erythema, tinea corporis, pityriasis rosea, pemphigus foliaceus, dermatitis herpetiformis, or a form of the variable erythrokeratodermias (2).

Histological examination is very important in differential diagnosis. In our cases, it was very helpful in correct diagnosis, although APP is similar to other types of pustular psoriasis. The image includes widening of superficial capillaries and perivascular lymphocytic infiltration, focal swelling of the skin, and spongiform Kogoj pustules (neutrophil infiltration of the necrotic areas of the skin). In some cases, subcorneal pustules are present because of cytolysis. Characteristic histological spongiform pustules can help distinguish APP from subcorneal pustular disease (3). Another disease that should be differentiated from APP is AGEP.
Kardaun et al. analyzed biopsy images for 29 patients with AGEP and 19 with GPP (24). They showed only minor differences in the acute phase of both diseases. Diluted capillaries in the papillary dermis in psoriasis were observed, whereas in AGEP leukocytoclastic vasculitis, edema, and eosinophilia in the dermis and necrotic keratinocytes may be present $(24,25)$. However, psoriasiform acanthosis is usually not very marked in APP. The histopathological picture is usually nonspecific, which might lead to misdiagnosis, and this is why some biopsies are needed (3).

APP responds well to retinoids, as in the cases presented. A good response to retinoids can be a confirmation of the diagnosis. Moreover, a rapid onset of action and efficacy tends to occur even sooner than in plaque psoriasis (9). Most of cases presented in the literature described the efficacy of acitretin. In the literature an efficacious alternative is methotrexate $(3,26)$. In contrast, using corticosteroids is controversial. They can rapidly limit the acute phase, but on the other hand their withdrawal can cause a "rebound" phenomenon $(1,13)$. A dose of $3 \mathrm{mg} / \mathrm{kg}$ of prednisolone for 3 days is proposed to obtain significant improvement results and then cyclosporine therapy should be continued to achieve remission (1). Recently, the high efficacy of anti-TNF antibodies, ustekinumab (anti-IL-12/23p40), and secukinumab (anti-IL-17) has been described $(12,17)$.

Topical treatment is similar to psoriasis: topically applied corticosteroids and analogs of vitamin D3. On the other hand, dithranol should be used with caution due to potential irritation. Good results are described after using PUVA (1). Topical treatment can be helpful with systemic management (etretinate, dapsone, and methotrexate) (3).

\section{References}

1. Albert A, Hein R, Ring J, Jakob T. Erythema annulare centrifugum-like psoriasis cum pustulatione. Hautarzt. 2007;58:769-73.

2. Vocks E, Worret WI, Ring J. Erythema annulare centrifugum-type psoriasis: a particular variant of acute-eruptive psoriasis. J Eur Acad Dermatol Venereol. 2003; 17:446-8.

3. Liao PB, Rubinson R, Howard R, Sanchez G, Frieden IJ. Annular pustular psoriasis-most common form of pustular psoriasis in children: report of three cases and review of the literature. Pediatr Dermatol. 2002;19:19-25.

4. Mzuashi M, Kuramoto Y, Aiba S, Tagami H. Juvenile localized annular pustular psoriasis developing severe exacerbation after topical indomethacin application. Int J Dermatol. 2009;48:1262-4.

5. Park YM, Kang H, Cho BK. Annular pustular psoriasis localized to the dorsa of the feet. Acta Derm Venereol. 1999;79:161-2.

6. Catharino A, Daiha E, Carvalho C, Martinez D, Lima RB, D’Acri A, et al. Possible correlations between annular pustular psoriasis and Noonan syndrome. J Eur Acad Dermatol Venereol. 2016;30:e195-e6.

7. Rosen RM. Annular pustular psoriasis induced by UV radiation from tanning saIon use. J Am Acad Dermatol. 1991;25:336-7.

8. Guill CL, Hoang MP, Carder KR. Primary annular plaque-type psoriasis. Pediatr Dermatol. 2005;22:15-8.

9. Haug V, Benoit S, Wohlleben M, Hamm H. Annular pustular psoriasis in a 14-month-old girl: a therapeutic challenge. J Dermatolog Treat. 2017;28:520-2.

10. Hubler WR. Familial juvenile generalized pustular psoriasis. Arch Dermatol. 1984;120:1174-8.

11. Prasertyothin S, Chularojanamontri L, Wongpraparut C, Silpa-archa N. Clinical characteristics and treatment outcomes of 53 pustular psoriasis patients. J Med Assoc Thai. 2017;100:565-72.

12. Takematsu H, Rokugo M, Takahashi K, Tagami H. Juvenile generalized pustular psoriasis in a pair of monozygotic twins presenting strikingly similar clinical courses. Acta Derm Venereol. 1992;72:443-4.

13. Lo Schiavo A, Brancaccio G, Puca RV, Caccavale S. Etanercept in the treatment of generalized annular pustular psoriasis. Ann Dermatol. 2012;24:233-4.

14. Braun-Falco O, Berthold D, Ruzicka T. Psoriasis pustulosa generalisata - Klassifikation, Klinik und Therapie. Hautarzt. 1987;38:509-20.
15. Claus S, Ziemer M, Simon JC, Treudler R. Coincidence of annular pustular psoriasis, pemphigus foliaceus, and leukocytoclastic vasculitis associated with chronic cholecystitis. J Dtsch Dermatol Ges. 2016;14:830-1.

16. Hara H, Makino T, Mizawa M, Seki Y, Hayashi M, Shimizu T. Annular pustular psoriasis associated with colon cancer. Eur J Dermatol. 2016;26:104-5.

17. Bachelez H. Pustular psoriasis and related pustular skin diseases. Br J Dermatol. 2018;178:614-8.

18. Duckworth L, Maheshwari MB, Thomson MA. A diagnostic challenge: acute generalized exanthematous pustulosis or pustular psoriasis due to terbinafine. Clin Exp Dermatol. 2012;37:24-7.

19. Naldi L, Gambini D. The clinical spectrum of psoriasis. Clin Dermatol. 2007;25: 510-8.

20. Tauber M, Bal E, Pei XY, Madrange M, Khelil A, Sahel H, et al. IL36RN mutations affect protein expression and function: a basis for genotype phenotype correlation in pustular diseases. J Invest Dermatol. 2016;136:1811-9.

21. Miyake T, Umemura H, Doi H, Kousogabe J, Tsuji K, Hamada T, et al. Annular pustular psoriasis with a heterozygous IL36RN mutation. Eur J Dermatol. 2015; 25:349-50.

22. Keller M, Spanou Z, Schaerli P, Britschgi M, Yawalkar N, Seitz M, et al. T cell regulated neutrophilic inflammation in autoinflammatory diseases. J Immunol. 2005;175:7678-86.

23. Satoh TK, Mellett M, Contassot E, French LE. Are neutrophilic dermatoses autoinflammatory disorders? Br J Dermatol. 2018;178:603-13.

24. Kardaun SH, Kuiper H, Fidler V, Jonkman MF. The histopathological spectrum of acute generalized exanthematous pustulosis (AGEP) and its differentiation from generalized pustular psoriasis. J Cutan Pathol. 2010;37:1220-9.

25. Bermejo MCS, Durán VR, Antich IA. Psoriasis pustulosa anular. Actas Dermosifiliogr. 2002;93:607-8.

26. Terunuma A, Takahashi K, Sakakibara A, Aiba S, Tagami H. Annular psoriasiform eruption with lymphocytic infiltration of the epidermis: a variant of acute psoriasis? Dermatology. 1992;185:156-9. 